\title{
KAJIAN FONOTAKTIK BAHASA INDONESIA
}

\author{
Zamzani \\ FBS Universitas Negeri Yogyakarta
}

\begin{abstract}
This research study aims to describe 1) phonotactics of syllables in Indonesian, and 2) phonotactics of words in Indonesian. The research subjects were all lexemes or words in Indonesian. They included original Indonesian words and adopted words from other languages, and monomorphemic and polymorphemic words. The object of the study was the phonotactics of syllables and words in Indonesian. The sources of the corpus were the researcher and Kamus Besar Bahasa Indonesia. The data were collected by 1 ) making predictions concerning the phoneme distribution probability, and 2) finding evidence for the phoneme distribution in the data sources or corpus. The data were analyzed by the distributional technique employing phoneme substitution and permutation. The research findings are as follows. First, there are 12 syllable patterns in the phonotactics of syllables in Indonesian. Each syllable has a nucleus which is obligatorily occupied by a vowel, with an onset and a coda being optional. An onset or a coda consists of at most three consonants. A three-consonant onset always consists of the first consonant $/ \mathrm{s} /$, the second $/ k$, $t$, or $\mathrm{p} /$, and the third $/ \mathrm{r} /$. A three-consonant coda is /-rps/ and is in the word korps only. Second, the phonotactics of words in Indonesian: 1) adjacency of a vowel and a vowel is acceptable as a syllable boundary, except $/-\mathrm{a}-$. - -ee -, - ou $-/$, and $/-\mathrm{o}-1,2$ ) adjacency of a vowel and a consonant is acceptable a syllable boundary, 3) adjacency of a consonant and a vowel acceptable as a syllable boundary is very limited, but as a syllable is very common so that the distribution of a consonant and a vowel is acceptable, and 4) adjacency of a consonant and another consonant is acceptable as a syllable boundary, and the distribution has a relationship with the phonotactics of syllables common in Indonesian.
\end{abstract}

Key words: phonotactics, syllable, nucleus, onset, coda

\section{A. Pendahuluan \\ 1. Latar Belakang}

Kata dalam suatu bahasa dapat dilihat sebagai satuan fonologis. Sebagai satuan fonologis, kata dalam suatu bahasa tentulah memiliki suatu sistem tertentu. Oleh karena itulah, setiap bahasa memiliki ciri khas dalam sistem fonologisnya. Setiap bahasa memiliki kekhasan dalam hal pemilikan khasanah fonem, dan struktur fonemis. Hal ini merupakan ciri keunikan yang ada pada setiap bahasa. Fonem yang sama dalam suatu bahasa belum tentu memiliki distribusi yang sama dalam dua bahasa yang berbeda. Hal itu discbabkan oleh 
adanya kaidah fonotaktik yang ada atau berlaku dalam suatu bahasa. Secara teoretik memang kaidah itu pasti telah ada dalam setiap bahasa, termasuk di dalamnya kaidah fonotaktik bahasa Indonesia, dan kaidah itu tentu telah menjadi "milik" komunitas bahasanya.

Khasanah fonem bahasa Indonesia telah dimaklumi mengalami perubahan sejalan dengan perkembangan bahasa itu sendiri. Perubahan itu disebabkan oleh terjadinya kontak bahasa Indonesia dengan bahasa lain. Kontak bahasa tersebut telah memberikan peluang pada bahasa Indonesia untuk menerima tambahan khasanah fonem baru. Hal itu ditandai oleh adanya kosa kata "baru” yang merupakan kosa kata serapan dari bahasa lain yang di dalamnya terdapat fonem yang sebelumnya tidak dimiliki oleh bahasa Indo-nesia. Dengan indikator fonem itu, dapat suatu kata dapat ditentukan apakah kata itu merupakan kata bahasa Indonesia "asli" atau bukan asli. Misalnya, semua kata yang di dalamnya terdapat fonem $/ f /, / x /, / 5 /$, dapat dipastikan merupakan kosa kata pinjaman (bukan asli) karena fonemfonem tersebut bukan merupakan fonem asli bahasa Indonesia. Penentuan khasanah fonem bahasa Indonesia itu sendiri sampai saat ini tidak terjadi persoalan yang berarti. Persoalan yang muncul adalah dengan masuknya khasanah fonem baru itu memberikan peluang terjadinya perubahan sistem fonem bahasa Indonesia (lihat Samsuri, 1985).

Selain apa yang dinyatakan di atas, kontak bahasa memberikan peluang adanya tambahan khazanah fonem dan perubahan struktur distribusi fonem. Hal itu berarti membuka peluang terjadinya pergeseran kaidah struktur fonemis yang merupakan kajian berikutnya setelah khazanah fonem baru ditemukan (lihat Samsuri, 1985).

Fonotaktik (ada pula yang menyebut struktur fonemis dari sebuah sistem fonem) bahasa Indonesia sampai saat ini belum ada yang melakukan kajian secara khusus. Namun demikian, penulis buku tata bahasa Indonesia pada umumnya telah memasukkan kaidah fonotaktik meski baru terbatas pada fonotaktik silabel atau suku kata. Itu pun belum sampai pada kaidah distribusi fonem. Memang, setidaknya telah ada dua buku yang secara sekilas memasukkan fonotaktik sampai lintas suku kata, yaitu struktur fonemis pada tataran kata (lihat Alwi, 1998, dan Depdiknas, 1990). Deskripsi kaidah fonotaktik yang tidak hanya terbatas pada suku kata itu sudah selayaknya dimiliki. Untuk menyusun kaidah fonotaktik ini tidak ada jalan lain selain melalui kegiatan kajian secara mendalam.

Atas dasar butir-butir di atas, perlu dilakukan penelitian dalam rangka mendeksripsikan fonotaktik bahasa Indonesia, baik pada tataran silabel maupun lintas silabel atau kata berdasarkan data bahasa Indonesia yang ada pada saat ini. Hal ini perlu dinyatakan, mengingat perkembangan bahasa Indonesia yang sanga pesat sehingga apa yang ada sekarang dalam waktu tidak terlalu lama berpeluang terjadi perubahan. 
2. Tujuan

Sesuai dengan uraian latar belakang masalah, tujuan penclitian ini dapat dinyatakan dalam dua butir, yaitu mendekripsikan (1) fonotaktik silabel, dan (2) fonotaktik kata bahasa Indonesia.

\section{Landasan Teori}

a. Konsep Fonotaktik

Kata merupakan deretan atau urutan bunyi yang bersifat linear, bunyi yang satu mendahului atau mengikuti bunyi yang lainnya. Bunyi yang terangkai dalam suatu kata itu merupakan bunyi yang mewakili fonem atau alofonnya. Rangkaian bunyi tersebut tidak sembarangan, melainkan memiliki suatu sistem kaidah yang biasa disebut fonotaktik (phonotactics). Pike (tt) tidak menggurakan istilah fonotaktik, tetapi memakai istilah struktur fonem. Dalam setiap bahasa terdapat struktur fonem yang berupa distribusi vokal dan konsonan.

Fonotaktik merupakan bagian dari bidang fonologi atau fonemik yang berupa kaidah struktur fonem dalam suatu bahasa. Kaidah fonotaktik itu merupakan konvensi dari komunitas pemakai bahasa itu sendiri. Sebagai konsekuensinya, dua bahasa yang berbeda meski memiliki jumlah fonem yang sama atau sejumlah fonem yang sama, distribusi fonemnya tentulah berbeda yang diakibatkan oleh adanya konvensi yang berbeda sehingga kaidah strukturnya berbeda, dan berbeda fonotaktiknya.

Pada umumnya para ahli bahasa sepaham bahwa fonotaktik membicarakan permasalahan struktur fonem. Hal tersebut dapat dilihat pada beberapa konsep fonotaktik oleh para ahli bahasa berikutini.

Kridalaksana (1982: 46) menyatakan bahwa fonotaktik meliputi tiga hal, yaitu merupakan (1) urutan fonem yang dimungkinkan dalam suatu bahasa, (2) deskripsi tentang urutan fonem tersebut, dan (3) gramatika stratifikasi, yaitu sistem pengaturan dalam stratum fonemik.

Fonotaktik merupakan kaidah yang mengatur penjejeran atau penderetan fonem dalam satu morfem (Alwi dkk., 1998: 28; Moeliono dan Dardjowidjojo, 1988: 23-24; Husain, 1993:49). Aturan penderetan fonem tersebut berdasarkan konvensi di antara pemakai bahasa itu sendiri sehingga bahasa yang satu dengan yang lainnya memiliki kaidah yang berbeda.

Dardjowidjojo (2003: 40) menyatakan dengan singkat bahwa fonotatik merupakan sistem pengaturan fonem. Tiap bahasa memiliki sistem sendiri-sendiri untuk menggabungkan fonem agar menjadi suku kata dan kemudian kata. Pendapat yang mirip diungkapkan Kentjono (1982: 34) yang menyatakan bahwa fonotaktik merupakan kaidah perangkaian fonem untuk membentuk satuan fonologis yang lebih besar, misalnya suku kata. Dua bahasa mungkin memiliki beberapa fonem yang sama, tetapi kaidah fonotaktiknya berbeda.

Dari konsep tersebut jelas bahwa fonotaktik merupakan sistem struktur fonem, tidak hanya terbatas pada sistem pengaturan fonem sampai pada tataran morfem, melainkan sampai pada tataran kata. Kata dalam suatu bahasa tentu saja ada kata berstruktur 
polimorfemik atau kata berstruktur kompleks dan ada kata berstruktur monomorfemik atau kata berstruktur sederhana.

\section{b. Tataran Fonotaktik}

Dengan prinsip bahwa fonotaktik merupakan kaidah perangkaian fonem untuk membentuk satuan fonologis, fonotaktik dapat dikelompokkan menjadi dua tataran, yaitu tataran silabel (suku kata) dan tataran kata. Hal itu didasarkan pada kenyataan bahwa satuan fonologis itu secara teoretis dapat berupa silabel dan kata.

Satuan fonologis silabel merupakan satu satuan lafal yang terdiri satu hembusan nafas (Alwi dkk., 1998: 55, Moeliono dan Dardjowidjojo, 1988: 44). Oleh karena itu, kriteria yang digunakan untuk menentukan suatu silabel adalah bagaimana pelafalannya. Selain itu, setiap silabel ditandai adanya sonoritas, dan sonoritas yang paling tinggi dimiliki oleh fonem-fonem vokalik. Atas dasar hal tersebut suatu silabel minimum terdiri atas satu bunyi yang bersifat vokalik, dan bunyi lainnya, yaitu bunyi-bunyi nonvokalik. Bunyibunyi vokalik biasanya berupa vokal, sedangkan bunyi nonvokalik berupa konsonan. Kehadiran konsonan dalam suatu silabel bersifat opsional.

Struktur silabel terdiri atas dua bagian, yaitu onset dan rima. Rima terdiri atas nukleus dan koda. Setiap silabel harus ada nukleus, dan nukleus terse but selalu berupa vokal. Konsonan atau konsonan-konsonan yang berada di depan nukleus dalam suatu silabel termasuk bagian yang disebut onset, dan yang berada di belakang vokal dalam satu silabel disebut koda. Onset dan koda bersifat opsional, sedangkan nukleus bersifat obligator atau wajib (lihat Dardjowidjojo, 2003: 42). Onset dan koda yang terdiri atas dua konsonan atau lebih disebut kluster atau gugus konsonan (Alwi dkk., 1998: 27, 52-53; Moeliono dan Dardjowidjojo, 1988:23, 42)

Pola suku kata yang ada dalam bahasa Indonesia telah dirumuskan oleh para ahli bahasa, meski terdapat perbedaan jumlah yang dihasilkan. Rumusan pola suku kata tersebut antara lain dapat dijumpai pada, Pedoman Umum Ejaan bahasa Indonesia yang Disempurnakan (PPPB, 1975), Dardjowidjojo (2003: 41), Kentjono (1982: 34), Moleliono dan Dardjowidjojo (1988: 66), dan Alwi dkk. (1998: 77). Bila pola silabel yang telah dirumuskan tersebut dibandingkan dalam bentuk matriks, sebagaimana tabel 1 .

Fonotatktik pada tataran di atas silabel yaitu fonotaktik tataran kata dalam bahasa Indonesia sampai sekarang belum ada yang mendeskripsikan secara lengkap. Ada beberapa penulis yang memberikan contoh distribusi konsonan dalam suatu kata yang tidak berterima dalam bahasa Indonesia. Distribusi konsonan yang dicontohkan tersebut merupakan distribusi sanding konsonan sebagai batas silabel. Misalnya, distribusi konsonan /-pk-/,/-mt-/, /-pd-/, dan /-kb-/ tidak berterima dalam bahasa Indonesia (Moeliono dan Dardjowidjojo, 1988: 24; Husain, 1993:49); distribusi /-pk-/ dan /pd-/ tidak terdapat dalam jejeran atau deretan fonem konsonan bahasa Indonesia (Alwi dkk., 1998: 28), dan 
Tabel 1: Matriks Perbandingan Pola Silabel Bahasa Indonesia

\begin{tabular}{|l|l|l|l|l|l|}
\hline \multirow{2}{*}{ No. } & \multicolumn{1}{|c|}{$\begin{array}{c}\text { PPPB } \\
(1975)\end{array}$} & \multicolumn{1}{|c|}{$\begin{array}{c}\text { Dardjowidjojo } \\
(2003)\end{array}$} & $\begin{array}{c}\text { Kentjono } \\
(1982)\end{array}$ & $\begin{array}{r}\text { Moeliono dan Dardjowidjojo } \\
(1988)\end{array}$ & $\begin{array}{c}\text { Alwi dkk. } \\
(1998)\end{array}$ \\
\hline $\mathbf{1}$ & $\mathrm{V}$ & $\mathrm{V}$ & $\mathrm{V}$ & $\mathrm{V}$ & $\mathrm{V}$ \\
\hline 2 & $\mathrm{VK}$ & $\mathrm{VK}$ & $\mathrm{VK}$ & $\mathrm{VK}$ & $\mathrm{VK}$ \\
\hline 3 & VKK & - & - & - & - \\
\hline 4 & KV & KV & KV & KV & KV \\
\hline 5 & KVK & KVK, & KVK & KVK & KVK \\
\hline 6 & KVKK & KVKK & KVKK & KVKK & KVKK \\
\hline 7 & KKV & KKV & KKV & KKV & KKV \\
\hline 8 & KKVK, & KKVK, & KKVK & KKVK & KKVK \\
\hline 9 & KKVKK & KKVKK & KKVKK & KKVKK & KKVKK \\
\hline 10 & KKKV & KKKV & KKKV & KKKV & KKKV \\
\hline 11 & KKKVK & KKKVK & KKKVK & KKKVK & KKKVK \\
\hline 12 & - & KVKKK & - & KVKKK & KVKKK \\
\hline
\end{tabular}

distribusi /-mg-/,/-mt-/, /-td-/, dan /-kg-/ selalu merupakan batas kata (Kridalaksana, 1985:17). Selain itu, ada pula yang memberikan contoh distribusi vokal dalam bahasa Indonesia. Misalnya, distribusi deretan vokal /-io-, -eə-, -eu-, -oe-, -ou-/, dan /-ua-/ tidak terdapat dalam bahasa Indonesia baku (Moeliono dan Dardjowidjojo, 1988: 52; Alwi dkk., 1998: 63).

Fonem-fonem yang tidak lazim berdampingan dalam suatu kata, bila muncul berdampingan dapat diartikan sebagi batas kata. Artinya, fonem yang satu sebagai bagian kata sebelumnya, dan fonem yang lainnya sebagai bagian kata berikutnya. Hal itu tidak dapat diartikan bahwa deretan fonem yang lain tidak dapat berposisi sebagai batas kata. Formulasinya harus dipahami bahwa bila deretan fonem yang tidak berterima muncul dalam suatu bahasa, keberadaanya dapat dipastikan sebagai batas kata, sedangkan dereten fonem yang berterima berada dalam suatu kata, pada kesempatan lain dapat memiliki potensi sebagai batas kata. Misalnya, d e r e $t$ a $n \quad f$ o $n$ m /tidaktahuentahmengapa/ dapat dipastikan vokal/-uə-/merupakan batas kata karena deretan /-uə-/ tidak berterima sebagai batas silabel dalam kata, dan batas kata yang lain penentunya bukan penyimpangan kaidah fonotaktik.

Berdasarkan uraian di atas tampak bahwa pendeskripsian fonotaktik dapat dilakukan pada dua tataran, yaitu tataran silabel dan tataran kata. Deskripsi fonotaktik silabel yaitu deskripsi tentang deretan fonem dalam silabel yang berterima dalam suatu bahasa. Sementara itu, deskripsi fonotaktik pada tataran kata dilakukan dengan sanding fonem, yaitu deretan fonem yang berterima saling berdekatan 
dalam suatu kata. Atas dasar kenyataan yang demikian, pendeskripsian fonotaktik tataran kata dalam penelitian ini dilakukan dengan sanding fonem.

\section{B. Metode Penelitian}

Subjek penelitian ini adalah semua kata bahasa Indonesia, baik kata asli bahasa Indonesia maupun kata pungutan/serapan dari bahasa lain, baik monomorfemik maupun polimorfemik. Objek penelitian ini adalah fonotaktik tataran silabel dan fonotaktik tataran kata.

Untuk menemukan kata bahasa Indonesia, selain peneliti sendiri dapat dijadikan sumber korpus, digunakan pula Kamus Besar Bahasa Indonesia yang sekali gus berfungsi sebagai alat validasi dalam rangka memastikan bahwa kata yang dimaksud memang telah masuk sebagai kosa kata bahasa Indonesia.

Cara pengumpulan data dalam penelitian ini dilakukan dengan langkah langkah berikut ini. Pertama, membuat prediksi peluang distribusi fonem berdasarkan banyaknya fonem yang ada dalam bahasa Indonesia, baik pada tataran silabel maupun tataran kata. Kedua, mencari bukti keberadaan distribusi dari sumber data, yaitu diri peneliti dan Kamus Besar Bahasa Indonesia.

Data dianalisis secara distribusional sehingga diperoleh deskripsi kaidah fonotaktik. Karena fonotaktik berkaitan dengan distribusi fonem, analisisnya dengan teknik substitusi dan permutasi fonem.

\section{Hasil Penelitian dan Pembahasan}

Berikut ini disajikan hasil sesuai dengan tujuan penelitian ini dan langsung diikuti dengan pembahasannya.

\section{Fonotaktik Silabel}

Pola silabel yang ditemukan sebanyak 12 pola dengan distribusi fonem sebagai pengisinya dapat disajikan dalam tabel 2 .

Tabel 2: Pola Silabel dan Distribusi Fonem Pengisi Silebel

\begin{tabular}{|c|c|l|l|}
\hline No. & $\begin{array}{c}\text { Pola } \\
\text { Silabel }\end{array}$ & \multicolumn{1}{|c|}{ Distribusi Fonem Pengisi Silabel } & \multicolumn{1}{|c|}{ Keterangan } \\
\hline 1. & V & $\begin{array}{l}\text { Vokal a, e, i, } \mathrm{u}, \mathrm{o}, \text { ? sebagai nukleus, tanpa onset } \\
\text { dan koda. }\end{array}$ & $\begin{array}{l}\text { Semua vokal dapat dapat berdiri } \\
\text { sebagai silabel }\end{array}$ \\
\hline 2. & VK & $\begin{array}{l}\text { Vokal sebagai nukleus, diikuti konsonan } \\
\text { sebagai koda: } \\
\text { a(b, d, } \mathrm{f}, \mathrm{h}, \mathrm{k}, \mathrm{l}, \mathrm{m}, \mathrm{n}, \mathrm{p}, \mathrm{r}, \mathrm{s}, \mathrm{t}, \mathrm{w}, \mathrm{x}, \mathrm{y}, \mathrm{z}, \mathrm{n}, \mathrm{\eta}) \\
\mathrm{e}(\mathrm{k}, \mathrm{l}, \mathrm{m}, \mathrm{n}, \mathrm{s}, \mathrm{n}, \mathrm{\eta}) \\
\mathrm{i}(\mathrm{b}, \mathrm{f}, \mathrm{j}, \mathrm{k}, \mathrm{l}, \mathrm{m}, \mathrm{n}, \mathrm{r}, \mathrm{s}, \mathrm{x}, \mathrm{n}, \mathrm{\eta}) \\
\mathrm{u}(\mathrm{l}, \mathrm{m}, \mathrm{n}, \mathrm{r}, \mathrm{s}, \mathrm{\eta}) \\
\mathrm{o}(\mathrm{b}, \mathrm{h}, \mathrm{l}, \mathrm{m}, \mathrm{n}, \mathrm{p}, \mathrm{r}, \mathrm{s}, \mathrm{n}, \mathrm{\eta}) \\
\text { (m, } \mathrm{n}, \mathrm{\eta})\end{array}$ & $\begin{array}{l}\text { Konsonan di dalam kurung } \\
\text { adalah konsonan yang dapat } \\
\text { berfungsi sebagai koda pada } \\
\text { silabel VK. } \\
\text { Data lengkap lihat pada lampiran } \\
\text { 1. }\end{array}$ \\
\hline 3 & VKK & $\begin{array}{l}\text { Vokal sebagai nukleus dikuti dengan deretan } \\
\text { konsonan sebagai koda: } \mathrm{V}(\mathrm{ks}, \mathrm{rt}, \mathrm{ns})\end{array}$ & $\begin{array}{l}\text { Terdapat pada kata: eks, ekspres, } \\
\text { ekstrim, art, ons }\end{array}$ \\
\hline
\end{tabular}




\begin{tabular}{|c|c|c|c|}
\hline 4 & $\mathbf{K V}$ & $\begin{array}{l}\text { Konsonan scbagai onset diikuti vokal scbagai } \\
\text { nukleus. Semua konsonan dapat mengisi onset, } \\
\text { dan semua vokal dapat mengisi nukleus }\end{array}$ & Tidak terdapat pengecualian \\
\hline 5 & KVK & $\begin{array}{l}\text { Konsonan sebagi onset diikuti vokal sebagai } \\
\text { nukleus, dan konsonan sebagai koda. Semua } \\
\text { konsonan dapat berposisi sebagai onset, semua } \\
\text { vokal dapat berposisi sebagai nukleus, dan } \\
\text { sebagian besar konsonan dapat berposisi } \\
\text { sebagai koda. }\end{array}$ & $\begin{array}{l}\mathrm{c}, \mathrm{d}, \mathrm{g}, \mathrm{x}, \mathrm{y}, \mathrm{z}, \text { tidak dapat } \\
\text { menjadi koda. }\end{array}$ \\
\hline 6 & KVKK & $\begin{array}{l}\text { Konsonan sebagai onset, diikuti vokal sebagai } \\
\text { nukleus, dan diikuti deretan dua konsonan } \\
\text { sebagai koda. Konsonan yang dapat berpsosisi } \\
\text { sebagai onset dan koda serta vokal sebagai } \\
\text { nukleusnya sangat terbatas. }\end{array}$ & $\begin{array}{l}\text { Onset berupa } t, d, l, h \text {, atau } p \text {, } \\
\text { nukleus e atau o, kodanya } \\
\text { berupa ks, rn, rt. Misalnya: teks, } \\
\text { konteks, intern, modern, rileks, } \\
\text { horn, import, eksport }\end{array}$ \\
\hline 7 & KVKKK & $\begin{array}{l}\text { Konsonan sebagai onset, diikuti vokal sebagai } \\
\text { nukleus, dan diikuti deretan tiga konsonan } \\
\text { sebagai koda: distribusi ini sangat terbatas. }\end{array}$ & $\begin{array}{l}\text { Hanya terdapat pada satu kata } \\
\text { korps. }\end{array}$ \\
\hline 8 & KKV & $\begin{array}{l}\text { Deretan dua konsonan sebagai onset, diikuti } \\
\text { vokal sebagai nukleus. Konsonan tertentu saja } \\
\text { yang dapat berdistribusi menjadi deret } \\
\text { konsonan. }\end{array}$ & $\begin{array}{l}\text { konsonan keduanya selalu } r \text { atau } \\
\text { l, didahu-lui } p, f, k, s, d, b, g \text { atau } \\
\text { t; dan } k \text {, p, w atau t hanya dapat } \\
\text { didahului s }\end{array}$ \\
\hline 9 & KKVK & $\begin{array}{l}\text { Deretan dua konsonan sebaga onset diikuti } \\
\text { vokal sebagai nukleus dan konsonan sebagai } \\
\text { koda. Konsonan tertentu saja yang dapat } \\
\text { berdistribusi menjadi deret konsonan. }\end{array}$ & 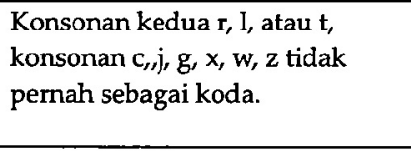 \\
\hline 10 & KKVKK & $\begin{array}{l}\text { Deretan tiga konsonan sebagai onset, diikuti } \\
\text { vokal sebagai nukleus, dan diikuti konsonan } \\
\text { sebagai koda. Deret konsonan yang dapat } \\
\text { berdistribusi sebagai onset dan koda sangat } \\
\text { terbatas. }\end{array}$ & $\begin{array}{l}\text { Konsonan onset terdiri atas pl } \\
\text { atau sp, dan kodanya ks atau rt. }\end{array}$ \\
\hline 11 & KKKV & $\begin{array}{l}\text { Deretan tiga konsonan sebagai onset, diikuti } \\
\text { vokal sebagai nukleus. Deret konsonan yang } \\
\text { dapat berdistribusi sebagai onset sangat } \\
\text { terbatas. }\end{array}$ & $\begin{array}{l}\text { Konsonan onset pertama selalu s, } \\
\text { kedua } t, k \text {, atau p; dan ketiga } r \\
\text { atau } 1 .\end{array}$ \\
\hline 12 & KKKVK & $\begin{array}{l}\text { Deretan tiga konsonan sebagai onset, diikuti } \\
\text { vokal sebagai nukleus, dan diikuti konsonan } \\
\text { sebagai koda. Deret konsonan yang dapat } \\
\text { berdistribusi sebagai onset, dan konsonan koda } \\
\text { sangat terbatas }\end{array}$ & $\begin{array}{l}\text { Konsonan onset pertama selalu } \mathrm{s} \text {, } \\
\text { kedua } t, k \text {, atau } p \text {, dan ketiga } r \\
\text { atau } 1 ; \text { konsonan kodanya } k, p \\
\text { atau } \mathrm{y} \text {. }\end{array}$ \\
\hline
\end{tabular}

Temuan fonotaktik silabel yang lebih populer disebut pola silabel atau suku kata tersebut menunjukkan adanya persamaan dan perbedaan dengan temuan sebelumnya atau setidaknya yang telah dideskripsikan sebelumnya. Persamaan dengan temuan sebelumnya antara lain, (1) setiap silabel ditandai oleh adanya satu sonoritas sebagai nukleus silebel, dan nukleus silebel ditempati oleh vokal, (2) semua vokal dalam bahasa Indonesoia dapat berdiri sendiri sebagai nukleus silabel tanpa didahului onset atau diikuti oleh koda, (3) sepuluh pola silabel yang sama dengan temuan sebelumnya, yaitu $\mathrm{V}$, VK, KV, KVK, KVKK, KKV, KKVK, KKVKK, KKKV, dan KKKVK. Perbedaannya, pada Kentjono (1982) belum dideskripsikan pola silabel VKK 
dan KVKKK, dalam Pedoman EYD (PPPB, 1975) belum dideskripsikan pola silabel KVKKK, dan dalam Mocliono dan Dardjowidjojo (1988), Alwi dkk. (1998) dan dalam Dardjowidjojo (2003) belum dideskripsikan VKK. Dengan pernyataan lain dapat dikatakan bahwa Kentjono (1982) baru mendeskripsikan 10 pola silabel bahasa Indonesia, dua pola silabel VKK dan KVKKK belum dideskripsikan, sedangkan yang lainnya mendeskripsikan 11 pola silabel bahasa Indonesia, dan pola silabel VKK atau KVKKK yang belum dideskripsikan.

Dengan adanya kata ons, eks, art, ekspor, ekstrem dalam bahasa Indonesia tidak ada alasan lagi untuk menyatakan bahwa silabel VKK tidak dijumpai dalam bahasa Indonesia. Mungkin, buku yang belum memasukkan pola silabel VKK tersebut karena terlewatkan saja. Hal tersebut dapat dipahami, karena pada buku yang lain telah dijumpainya.

Dengan adanya kata korps dan memang baru satu-satunya, silabel berpola KVKKK dapat dinyatakan berterima dalam bahasa Indonesia. Pola silabel tersebut belum dideskripsikan dalam Pedoman EYD (PPPB, 1975), tetapi telah dideskripsikan dalam $B u k u$ Tata Bahasa Baku Bahasa Indonesia (semua edisi), dan pada buku-buku lainnya.

Terlepas dari perbedaan deskripsi tersebut, penelitian ini ternyata telah menemukan fakta adanya fonotaktik silabel yang oleh buku tertentu telah dianggap sebagai pola silabel bahasa Indonesia, namun pada buku lainnya belum dimasukkan. Setidaknya, temuan ini membuktikan bahwa penelitian yang terbaru sebaiknya lebih lengkap dan akurat daripada yang dilakukan oleh orang sebelumnya. Selain itu, bahasa Indonesia mengalami perkembangan sehingga mungkin ditemukan pola silabel yang baru masih terbuka.

Onset dalam bahasa Indonesia maksimum terdiri atas tiga konsonan. Semua konsonan dapat mengisi onset yang terdiri atas satu konsonan. Onset yang terdiri atas dua konsonan, konsonan pertama dapat berupa / $\mathrm{p}, \mathrm{f}, \mathrm{k}$, $\mathrm{s}, \mathrm{d}, \mathrm{b}$, atau g/; dan konsonan keduanya dapat berupa $/ r, 1, k, p, w$ atau $t /$. Adapun kaidahnya adalah konsonan keduanya selalu /r atau 1/, didahului /p, f, k, s, d, b, $\mathrm{g}$, atau $\mathrm{t} / ; \operatorname{dan} / \mathrm{k}, \mathrm{p}, \mathrm{w}$ atau $\mathrm{t} / \mathrm{hanya}$ dapat didahului $/ \mathrm{s} /$. Onset yang terdiri atas tiga konsonan memiliki kaidah: konsonan pertama selalu /s/, kedua /t, $\mathrm{k}$, atau p/; dan ketiga $/ \mathrm{r}$ atau $1 /$.

Koda dalam bahasa Indonesia maksimum terdiri atas tiga konsonan. Koda yang térdiri atas satu konsonan dapat diisi oleh semua konsonan. Artinya, semua konsonan yang ada dalam bahasa Indonesia dapat berposisi sebagai koda yang terdiri atas satu konsonan. Meski demikian, faktor vokal nukleus memiliki peranan dalam menentukan distribusi konsonan kodanya. Misalnya, nukleus $/ \partial /$ hanya dapat diikuti dengan koda $/ \mathrm{m}, \mathrm{n}$, atau $\eta /$; nukleus $/ \mathrm{u} /$ hanya dapat diikuti dengan koda $h, \mathrm{~m}, \mathrm{n}, \mathrm{r}, \mathrm{s}$, atau $\eta /$. Selain itu, faktor onset juga memiliki peranan sebagai penentu distribusi kodanya. Misalnya, bila onsetnya terdiri atas dua konsonan, konsonan $/ c, j, g, x, w$, dan $z /$ tidak pernah dapat berposisi sebagai koda; bila onsetnya terdiri atas tiga konsonan, konsonan kodanya $/ \mathrm{k}$, $\mathrm{p}$ atau 
1y/. Koda yang terdiri atas dua konsonan, terbatas pada distribusi $/ \mathrm{ks}$, $\mathrm{rt}_{\text {, }} \mathrm{ns}$ atau $\mathrm{rn} /$. Dalam distribusi koda tersebut juga sangat terbatas. Misalnya, koda /ns/ hanya terdapat pada ons, karena kata asing yang berkoda ns cenderung menjadi koda $/ \mathrm{n} /$, seperti respons dinaturalisasi menjadi respon. Koda yang terdiri atas tiga konsonan berupa rps yang sampai saat ini hanya terdapat pada satu kata, yaitu korps.

Dari pembahasan di atas dapat disimpulkan bahwa fonotaktik silabel bahasa Indonesia terdapat 12 pola silabel, yaitu V, VK, VKK, KV, KVK, KVKK, KVKKK, KKV, KKVK, KKVKK, KKKV, dan KKKVK. Setiap silabel memiliki nukleus yang bersifat wajib yang diisi oleh vokal, sedangkan onset dan koda berifat opsional. Onset dalam bahasa Indonesia maksimum terdiri atas tiga konsonan dengan ketentuan konsonan pertama selalu /s/, kedua / $\mathrm{k}$, atau p/, dan ketiga selalu /r/. Koda dalam bahasa Indonesia maksimum terdiri atas tiga konsonan, dan koda tiga konsonan /rps/ khusus terdapat pada kata korps.

\section{Fonotaktik Kata}

Untuk penyajian hasil sekali gus pembahasana fonotaktik tataran kata, pada bagian ini disajikan tiga kelompok sanding fonem, yaitu (a) sanding vokal, dengan vokal, (b) sanding Vokal dengan konsonan, dan (c) sanding konsonan dengan konsonan.

\section{a. Sanding Vokal dengan Vokal}

Sanding vokal dalam suatu kata yang mungkin dapat terjadi terdapat 36 dari enam vokal yang ada dalam bahasa
Indonesia. Ketiga puluh enam sanding vokal tersebut adalah /-aa- , -ao-, -au-, ai-, -ae-, -aә-, -oa- , -oo-, -ou-, -oi-, -oe-, оә-, -ua-, -uo-, -uu-, -ui-, -ue-, -uə-, -ia- , io-, -iu-, -ii-, -ie-, -iə-, -ea-, -eo-, -eu-, -ei-, еe-, -еә-,- әа- , - әо-, - әи-, - әі-, - әе-, - әә-/. Dari 36 sanding vokal tersebut yang tidak ditemukan datanya dalam bahasa Indonesia ada lima sanding vokal, yaitu /-aə-, -ee-, -eə-, -ou-, -oə-/, dan yang 31 sanding vokal lainnya dapat ditemukan datanya. Hal itu dapat diartikan bahwa deret vokal /-aə-, -ee-, -eə-, -ou-, -оә-/ tidak berterima dalam bahasa Indonesia. Dengan pernyataan lain, deret vokal /aə-, -ee-, -eə-, -ou-, -oə-/ merupakan batas kata dalam bahasa Indonesia.

Sebagai catatan perlu disadari bahwa sanding vokal dalam pelafalan memberikan peluang munculnya fona tertentu. Pada sanding vokal yang identik (deret /-aa-, -uu-, -ii-, -oo-, dan D이-/) dalam pelafalan akan muncul bunyi hamzah atau glotal stop. Pada sanding vokal/-uo-, -ui-, dan ua-/ dalam pelafalan akan muncul bunyi [w], dan pada sanding vokal/-ia-, dan iu-/ dalam pelafalan akan muncul bunyi [y]. Pemunculan fona-fona diantara deret vokal tersebut bersifat prediktif sehingga fona-fona itu tidak berstatus sebagai fonem.

Temuan mengenai distribusi vokal yang tidak berterima di atas bila dibandingkan dengan deskripsi Moeliono dan Dardjowidjojo (1988: 52) dan Alwi dkk. (1998: 63) yang menyatakan bahwa deretan vokal/-i@-, eœ-, -eu-, -oe-, -ou-, dan -u(-/ tidak terdapat dalam bahasa Indonesia baku, hanya terdapat dua kesamaan, yaitu sanding vokal /-ee- dan -ou-/. Dua 
sanding vokal yang tidak ditemukan dalam penelitian ini, yaitu deret /-a@dan /-ee-/ justru tidak dinyatakan sebagai sanding vokal yang tidak baku dalam bahasa Indonesia versi kedua sumber tersebut. Empat sanding vokal/iø-, -eu-, -oe-, dan -u@-/ yang dinyatakan tidak terdapat dalam bahasa baku versi kedua sumber tersebut, dalam penelitian ini justru ditemukan sebagai deret vokal yang berterima. Sanding vokal /-i@-/ ditemukan pada kata yang berafiks \{di-\}dengan bentuk dasar yang dimulai dengan vokal /0)/. Misalnya, pada kata dientaskan, dieram. Sanding vokal /-eu-/ terdapat pada kata reuni. Sanding vokal /-oe-/ terdapat kata koeksistensi. Sanding vokal /-uه-/ terdapat padakatakonstituen.

Dalam bahasa Indonesia bila terdapat deret dua vokal yang berterima dapat dipastikan merupakan batas silabel. Hal itu dapat dipahami karena setiap silabel terdapat satu nukleus, dan nukleus itu berupa vokal. Misalnya, siang, buang, raut, soal. Sanding vokal yang tidak berterima dalam bahasa Indonesia merupakan batas kata. Misalnya, ada deret /baksouday/dapat dipastikan sanding vokal /-ou-/ merupakan batas kata karena sanding vokal /-ou-/ tidak berterima dalam batas silabel bahasa Indonesia.

\section{b. Sanding Vokal dengan Konsonan}

Sanding vokal dengan konsonan dalam konsep ini berupa urutan vokal diikuti dengan konsonan seb agai batas silabel suatu kata. Dari 21 konsonan dan 6 vokal dapat diprediksi adanya peluang sanding vokal dengan konsonan sebanyak 126 sanding fonem, seperti sanding vokal-konsonan:/-ab-, ac-, -ad-, -af-, -ag-, -ah-/. Dari 126 sanding vokal-konsonan tersebut, terdapat 123 sanding fonem yang berterima, dan tiga sanding fonem tidak ditemukan datanya, yaitu sanding fonem /-eń-, ex, dan -ox-/. Hal ini tidak dapat diartikan bahwa deretan vokalkonsonan /-eń-, ex- dan -ox-/ dalam bahasa Indonesia bereksistensi sebagai batas kata. Artinya, bila dalam suatu tuturan terdapat deretan vokalkonsonan /-eń-, -ex- atau -ox-/, vokal sebagai bagian kata sebelumnya, dan konsonan sebagai bagian kata berikutnya tidak dapat diterima begitu saja. Hal itu disebabkan oleh adanya peluang konsonan sebagai koda dalam suatu silabel. Misalnya, sanding vokalkonsonan /-eń-/ pada kata penceng dan enceng tidak berstatus sebagai batas kata, dan/-ń-/merupakan koda silabel.

Temuan di atas menunjukkan bahwa sebagian besar sanding vokalkonsonan sebagai batas silabel berterima dalam bahasa Indonesia. Hanya sedikit sekali, yaitu sanding vokal-konsonan eń-, ex, dan -ox-yang tidak berterima. Hal itu terkait dengan pola silabel kata bahasa Indonesia (K)V-KV yang sangat lazim dalam bahasa Indonesia. Pola tersebut dapat dibaca bila di tengah kata terdapat konsonan di antara dua vokal, batas silabelnya berada di depan konsonan. Oleh karena itu, sanding vokal-konsonan sebagai batas silabel sangat lazim.

\section{c. Sanding Konsonan dengan Vokal} Sanding konsonan vokal dalam hal ini merupakan urutan konsonan diikuti vokal sebagai batas silabel suatu 
kata. Seperti halnya sanding vokalkonsonan, sanding konsonan-vokal dapat diprediksi adanya peluang sanding konsonan dengan vokal sebanyak 126 sanding fonem, seperti sanding konsonan-vokal:/-ba-, -ca-, -da-, -fa-, -ga-, -ha-, -ja-, -ka-/. Dari 126 sanding konsonan-vokal tersebut, hanya ditemukan 15 sanding konsonan-vokal sebagai batas silabel, yaitu /-ba-/ pada subagen, /-la-/ pada dinulakhirat, /-li-/ pada aliman, /-ma-/ pada Jumat; /-na-/ pada nonaktif, /-ra-/ pada alquran, niraksara, /-bu-/ pada subunit;/-bi-/ pada subinti, subinduk, /-bo-/ pada subordinasi, subordinat, /-be-/ pada subedisi, /-ne-/ pada nonelektrik, /-no-/ pada nonorganik, /-nu-/ nonusaha, /-ni-/ noninti, nonistilah, dan/-di-/pada/adinterim/.

Sebagian besar sanding konsonan-vokal tidak ditemukan sebagai batas silabel. Hal itu tidak berarti bahwa sanding konsonan-vokal dalam kata bahasa Indonesia sebagai besar tidak berterima. Sanding konsonanvokal dalam bahasa Indonesia dalam kenyataannya justru dominan sebagai silabel. Oleh karena itu, dalam bahasa Indonesia terdapat suatu kaidah: bila di dalam tengah kata terdapat konsonan yang diapit oleh dua vokal, batas silabelnya terletak di depan konsonan. Dengan demikian, kehadiran sanding konsonan-vokal dalam kata bahasa Indonesia sangat lazim, dan pada umumnya sebagai silabel bukan sebagai batas silabel.

\section{d. Sanding Konsonan dengan Konsonan}

Sanding konsonan dengan konsonan dalam bagian ini merupakan urutan atau jejeran konsonan diikuti konsonan sebagai batas silabel suatu kata. Dari 21 konsonan yang ada dalam bahasa Indonesia dapat diprediksi peluang sanding konsonan-konsonan sebanyak 441 sanding fonem, seperti /bb-, -bc-, -bd-, -bf-, -bg-/. Dari 441 sanding konsonan-konsonan sebagai batas silabel tersebut yang dapat ditemukan datanya hanya 189 , dan yang 252 tidak ditemukan datanya. Sanding konsonan-konsonan yang ditemukan datanya, misalnya /bc-/ pada subcabang, /-bd-/ pada abdi, /-bn-/ pada abnormal. Sanding konsonan-konsonan yang ada datanya dapat diartikan berterima sebagai distribusi fonotaktik dalam bahasa Indonesia.

Secara lengkap sanding konsonan-konsonan dapat yang berterima tersebut adalah /-bb-, -bc-, -bd, -bf-, -bg-, -bh-, -bj-, -bk-, -bl-, -bn-, -bp, -br-, -bs-, -bt-, -bw-, -by-, -bn'-, -df-, -dh-, -dj-, $\quad$-dk-, -dl-, -dm-, -dn-, -dp-, -dr-, ds-, -dw-, -dń-, -fd-, -fh-, -fk-, -fl-, -fr-, -fs-, -ft-, -fw-, -fń-, -gf-, -gd-, -gf-, -gl-, -gm-, gn-, -gr-, -hb-, -hd-, -hf-, -hk-, -hl-, -hm-, -hn-, -hr-, -hs-, -ht-, -hw-, -hy-, -hn'-, -jm-, - jn-, - -jr-, -jt-, -jw-, -kb-, -kc-, -kd-, -kj-, -kk-, -kl-, -km-, -kn-, -kp-, -kr-, -ks-, -kt-, -kw-, ky-, -kń-, -lb-, -ld-, -lf-, -lg-, -lh-, -lj-, -lk-, 11-, -lm-, -lp-, -lx-, -ls-, -lt-, -lw-, -ly-, -lń-, mb-, -mf-, -mh-, -mk-, -ml-, -mm-, -mn-, -mp-, -mr-, -ms-, -mt-, -mń-, -nb-, -nc-, nd-, -nf-, -nj-, -ng-, -nk-, -np-, -nr-, -ns-, nt-, -nw-, -nz-, -nń-, -pf, -pk-, -pl-, -pm-, pr-, -ps-, -pt-, -pń-, -rb-, -rc-, -rd-, -rf-, rg-, -rh-, -rj-, -rk-, -rl-, -rm-, -rn-, -rp-, -rs-, -rt-, -rw-, -ry-, -rz, -rń-, -sb-, -sc-, -sf-, -sg-, -sh-, -sj-, -sk-, -sl-, -sm-, -sn-, -sp-, -sr-, -st-, -sw-, $\quad$-sń-, -tc-, - -tk-, -tl-, -tm-, -tn-, -tr-, ts-, -tw-, -tń-, -xb-, -xl-, -xs-, -xt-, -xw-, - 
zm-, -ńc-, -ñj-, -nb, -nc-, -ng-, -nh-, -nk-, nl-, -np-, -nr-, -ns-, -nx-; -nń-. Sanding konsonan-konsonan yang tidak ditemukan datanya, misalnya /-bm-, -bx, -by-, -bz-, -cb-, -cc-, dan cd-/. Sanding konsonan-konsonan yang tidak ditemukan datanya tersebut merupakan sanding fonem yang tidak berterima, dan bereksistensi sebagai batas kata. Hal itu dapat diartikan bahwa dalam bahasa Indonesia terdapat 252 sanding konsonan-konsonan bereksis-tensi sebagai batas kata.

Di antara 189 sanding fonem yang berkedudukan sebagai batas silabel tersebut terdapat dua hal yang menarik. Pertama, pola kluster silabel memiliki hubungan dengan fonotaktik tataran kata. Artinya, konsonankonsonan yang dapat berdistribusi sebagai kluster memiliki perilaku yang sama sebagai batas silabel. Hal itu dapat didukung oleh kenyataan bahwa semua konsonan yang dapat bersanding sebagai kluster dapat bersanding sebagai batas silabel. Kedua, konsonan yang tidak pernah berposisi sebagai koda berperilaku yang khas, yaitu hanya dapat bersanding konsonan-konsonan dengan posisi di belakang, yaitu sebagai onset silabel berikutnya. Dengan perkataan lain, semua konsonan yang tidak dapat berposisi sebagai koda, tidak dapat berposisi di depan dalam sanding konsonan-konsonan batas silabel.

Temuan tersebut bila dibandingkan dengan pernyataan yang pernah dimunculkan oleh para ahli bahasa sebelumnya terdapat beberapa perbedaan. Pertama, temuan penelitian ini telah dapat memberikan deskripsi secara lengkap mengenai fonotaktik sanding konsonan-konsonan dalam bahasa Indonesia, sedangkan yang pernah dimunculkan oleh para ahli bahasa sebelumnya hanya sebagai contoh. Jadi, belum merupakan deskripsi yang utuh. Kedua, contoh mengenai fonotaktik sanding konsonankonsonan yang oleh para ahIi bahasa sebelumnya sebagai distribusi sanding konsonan yang tidak berterima dalam bahasa Indonesia, dalam penelitian ini ada beberapa yang ternyata telah berterima.

Secara rinci pembandingan temuan penelitian ini dengan contoh sanding konsonan-konsonan sebagai batas silabel yang diberikan oleh para ahli dapat disajikan berikut ini. Pertama, distribusi konsonan/-pk-, -mt-, -pd-, dan -kb-/ tidak berterima dalam bahasa Indonesia menurut Moeliono dan Dardjowidjojo (1988: 24) dan Husain (1993:49) dalam penelitian ini ditemukan data adanya distribusi /-pk-, -mt-, dan kb-/. Jadi, hanya distribusi /-pd-/ yang tidak ditemukan datanya, yang berarti hanya satu yang diperoleh kesamaan. Kedua, distribusi/-pk-/dan/pd-/ tidak terdapat dalam jejeran atau deretan fonem konsonan bahasa Indonesia menurut Alwi dkk. (1998: 28), distribusi /-pd-/ yang tidak ditemukan datanya. Ketiga, distribusi /-mg-, -mt-, $\mathrm{td}-$, dan $-\mathrm{kg}-/$ selalu merupakan batas kata menurut Kridalaksana (1985:17), ditemukan distribusi /-mt-/ dalam kata bahasa Indonesia, misalnya tamtama, amtenar, asumtif, konsumtif. Jadi, terdapat satu temuan distribusi yang berbeda, dan lainnya sama.

Dari pe m b h a s a pembandingan dengan temuan 
sebelumnya ini, tampak bahwa distribusi fonem yang sebelumnya tidak berterima, dalam perkembangan selanjutnya mungkin menjadi berterima. Hal itu terjadi karena bahasa Indonesia berkembang terus terutama dalam bidang kosa kata. Sebagai akibatnya, mungkin kosa kata baru tersebut berfonotaktik baru, yang berarti menambah khasanah sistem fonotaktik bahasa Indonesia.

\section{Simpulan}

Fonotaktik silabel dalam bahasa Indonesia terdapat 12 pola silabel, yaitu V, VK, VKK, KV, KVK, KVKK, KVKKK, KKV, KKVK, KKVKK, KKKV, dan KKKVK. Setiap silabel memiliki nukleus yang bersifat wajib yang diisi oleh vokal, sedangkan onset dan koda berifat opsional. Onset dan koda dalam bahasa Indonesia maksimum terdiri atas tiga konsonan. Onset tiga konsonan terdiri atas, konsonan pertama selalu fonem / $/$ /, konsonan kedua $/ k, t$, atau $p /$, dan konsonan ketiga selalu $/ r /$. Koda tiga konsonan hanya /-rps/ khusus terdapat pada kata korps.

Fonotaktik pada tataran kata dilihat dari sanding fonem sebagai batas silabel secara umum dapat dirangkum sebagai berikut.

Semua vokal dapat bersanding dengan dalam suatu kata dan berada dalam batas silabel, kecuali sanding vokal/-aø)-, -ee-, -e@-, -ou-, dan -oø-/.

Sanding vokal dengan konsonan sebagai batas silabel berterima dalam bahasa Indonesia. Fonotatktik seperti ini terkait dengan pola suku kata $(\mathrm{K})(\mathrm{K})(\mathrm{K}) \mathrm{V}-(\mathrm{K})(\mathrm{K}) \mathrm{V}$.

Sanding konsonan dengan vokal sebagai batas silabel yang berterima dalam bahasa Indonesia sangat terbatas. Meski demikian, lazim sekali silabel berstruktur konsonanvokal, baik diikuti dengan koda maupun tidak.

Sanding konsonan dengan konsonan dapat dirinci sebagai berikut. Pertama, pola kluster silabel memiliki hubungan dengan fonotaktik tataran kata. Sanding konsonan-konsonan yang dapat berdistribusi sebagai kluster memiliki perilaku yang sama sebagai batas silabel. Kedua, konsonan yang tidak pernah berposisi sebagai koda silabel berperilaku yang khas, yaitu hanya dapat bersanding konsonan-konsonan dengan posisi di belakang, yaitu sebagai onset silabel berikutnya.

\section{DAFTAR PUSTAKA}

Alwi, Hasan dkk. 1998. Tata Bahasa Baku Bahasa Indonesia. Jakarta: Balai Pustaka.

Dardjowidojo, Soenjono. 2003.Psikolinguistik: Pengenatar Pemahaman Bahasa Manusia. Jakarta: Yayasan Obor Indonesia.

Keraf, Gorys. 1991. Tata bahasa Rujukan Bahasa Indonesia. Jakarta: Grasindo.

Kridalaksana, Harimurti. 1985. Tata Bahasa Deskriptif Bahasa Indonesia. Jakarta: Pusat Pembinaan dan Pengembangan Bahasa, Depdikbud. 
1982. Kamus Linguistik. Jakarta: Gramedia.

Moeliono, Anton M. dan Soenjono Dardjowidjojo (Penyunting). 1988. Tata Bahasa Baku Bahasa Indonesia. Jakarta: Balai Pustaka.

Pike, Knenth L. tt. Phonemics: A Tachnique for Reducing Language to Wrting. Ann Arbor: The University of Michigan Press.
Soeparno. 2002, Dasar-dasar Linguistik Umum. Yogyakarta: Tiara Wacana Yogya.

Depdikbud. 1994. Kamus Besar bahasa Indonesia. Jakarta: Balai Bahasa.

Verhaar, J.W.M. 1977. Pengantar Linguistik. Yogyakarta: Gadjah Mada University Press. 